\title{
THE RESIDENCE PLOT SELECTION MODEL FOR FAMILY HOUSE IN VILNIUS BY NEUTROSOPHIC WASPAS METHOD
}

\author{
Romualdas BAUŠYS (D), Birutė JUODAGALVIENĖ, Rytė ŽIŪRIENĖ (D, \\ Ina PANKRAŠOVAITĖ (D), Juozas KAMARAUSKAS, Ana USOVAITĖ, \\ Dovydas GAIŽAUSKAS (D)
}

\author{
Vilnius Gediminas Technical University, Sauletekio al. 11, LT-10223 Vilnius, Lithuania
}

Received 20 June 2019; accepted 21 January 2020

\begin{abstract}
Good quality dwelling and the environment are related to the values of citizens' existence. It can be highlighted as important questions in creating a sustainable living environment. The research and analysis carried out so far include global planning of the plot of a particular country or city according to economic aspects. Meanwhile, our model, which covers the key social aspects of choosing a residential house, will fill this gap. We propose an original problem formulated which includes the planning of the plot of a particular city according to economic, environmental and social aspects. Our work aims to investigate the criteria for the selection of single-family houses and to develop a theoretical evaluation model based on decision-making methods. The presented study deals with the problem of selecting a one-family house plot using the Weighted Aggregate Sum Product Assessment Methods (WASPAS) and the Step-Wise Weight Assessment Ratio Analysis Method (SWARA). During the research, parameters related to plot selection were evaluated: infrastructure, distance, cost, privacy, security and aesthetic view.
\end{abstract}

Keywords: residence plot, infrastructure, MCDM, SWARA, WASPAS, neutrosophic set.

\section{Introduction}

The European Union Housing Sector Statistics Directive emphasises that affordable housing at affordable prices is a fundamental human need and right. Satisfying this need and thus reducing poverty and social exclusion in some European countries is still not easy (Eurostat, 2019). Approximately one-third of the population lives in singlefamily houses in Lithuania, and this indicator equals the EU average (Eurostat, 2019). In Europe, around 72\% of the population lives in cities (Hiller \& Lerbs, 2016). To help settle down, the urbanisation of cities is going beyond urban areas (European Environment Agency, 2015). 66.7\% of the population lives in Lithuanian cities, of which even a quarter - in Vilnius and its suburb (Lithuanian Department of Statistics, 2013), so a frequent resident chooses to build a residential house in the countryside (near Vilnius). Therefore, the most relevant criteria that influence the selection of single-family house plots in different locations of Vilnius and its suburbs are included in the formulation of our task.
At present, buildings, building elements and their environmental impact can be measured using BREEAM (Building Research Establishment Environmental Assessment Methodology) and LEED (Leadership in Energy and Environmental Design) certification systems covering all sustainability characteristics or other standards for sustainable building assessment. Unfortunately, even in the city of Vilnius (not to mention other Lithuanian cities), investment in the BREEAM and LEED residential building is hard to pay because it is $1000-5000$ euros per apartment with the BREEAM and LEED badge. What is more, these specific methods are not widely used in distinctive residential design because of the complex evaluation of many criteria. The introduction of BREEAM and LEED standards systems and the pursuit of certificates require additional investment (Construction and Architecture, 2018), which is why most individual home builders are too expensive. This fact is why new proposals for assessing the construction of single-family houses are emerging (Zavadskas et al., 2017a). In the meantime, our proposed model makes it easy for the average user who does not

*Corresponding author. E-mail: romualdas.bausys@vgtu.lt 
have special construction education to solve the problem of a site selection.

Analysts at Ober-Haus, a major real estate services company in Lithuania and the Baltic region, providing professional house, flat and land-plot search services highlight the growing demand for individual land-plots (OberHaus, 2019). This company captures demand growth in Lithuania: purchasing of land-plot in Lithuania increased by $83 \%$ compared to 2009 . Among the reasons are a lack of alternatives and a small price difference between a house and a flat. The company's analysts emphasise that a well-chosen plot is a great real estate investment. As a result, our proposed theoretical approach to site selection may be applicable to other European cities.

There is no doubt - own house is one of the biggest dreams of the people in Lithuania. Already today, most people buy and build houses, assessing their real possibilities. Research carried out over two decades ago analysed citizens' intuitive choice of housing environment and justified price dependence on the type of landscape (Luttik, 2000). What kind of house and place to choose to improve the quality of life and not reduce it? For Lithuanians, as well as for the majority of residents of other countries, the quality housing purchased is equivalent to a successful and long-term investment (Kaklauskas et al., 2018a). A citizen who owns a land-plot for a single-family home can live in that environment for the rest of his life, and future generations often inherit it. Consequently, landplot selection is no less important than the materials and constructions of the future house (Ortiz et al., 2016), energy use (Kaoula \& Bouchair, 2020), environmental impact (Motuziené et al., 2016; Petrovic et al., 2019). Before starting the building of a house, a land-plot is selected/ purchased: in the city, on the border of the city or outside the city. It often takes several years to find a land-plot for building a house trying to evaluate the infrastructure (Saidi et al., 2018), distance from the city center or workplace (Acheampong, 2018; Guidon et al., 2019), transport systems, communications (Saidi et al., 2018). Also, citizen choice is influenced by the structure of cities (Acheampong, 2018), the changing composition of their families (Fatmi \& Habib, 2018), a land-use change associated with spatial planning (Solecka et al., 2017). The pursuit of housing privacy, security, and aesthetic representations of the environment in research are presented as distinct social dimensions that affect the well-being of the population (Tao, 2018; Zamani et al., 2018). Most scientific articles on the house or plot selection assess 1-3 criteria, such as the development of a public transport network (Erdogan \& Kaya, 2019), landscape, distance to the workplace, or merely assessing citizens health rehabilitation. A study covering the economic, environmental and social (with emphasis on the latter) selection criteria was not widely developed. We propose a complex theoretical model for the selection of a single-family house plot. Our proposed model combines all the current most popular aspects, covering the anchors of sustainability: social, environmental and economic.
Thus, plot selection can be identified as an important area requiring specific consideration. As researches do not distinguish single-family house plots as a separate element - very important for the citizen intending to build a house - this task can be described as an actual procedure for engineering design and practical implementation (Mardani et al., 2017; Kaklauskas et al., 2018b; Kokaraki et al., 2019).

The selection process is a typical problem of multicriteria decision-making methods (MCDM) to reduce the number of possible alternatives for the final choice. MCDM approaches measure not only conflicting criteria (Si et al., 2016) but also integrate sustainability aspects: economic, environmental and social (Mohammed et al., 2019). Different MCDM approaches may be chosen for solving sustainability tasks. For example, Zavadskas et al. (2019) proposed a new methodology for assessing the safety of public parks, which includes a sustainable solution to determine the set of public parks according to their level of safety. The combination of Analytical Hierarch Process (AHP) and Technique for Order Preference by Similarity to Ideal Solution (TOPSIS) has been adapted to determine suitable locations for wind farms (Konstantinos et al., 2019). The Weight Aggregated Sum Product Assessment Methods (WASPAS), previously presented by Zavadskas et al. (2012), is used to solve different tasks: evaluating supplier services (Pamucar et al., 2019), developing a model for identifying critical information infrastructure (Turskis et al., 2019b), improving the quality of life (Baušys \& Blackhead, 2017), addressing the problem of local gathering (Chen et al., 2018) and others.

The development and application of WASPAS are analysed and systematised (Mardani et al., 2017, 2018), and various extensions are created for solving different tasks (Peng \& Dai, 2017; Mishra \& Rani 2018; Bausys et al., 2019). Because the plot selection problem can be identified as a city or country sustainability problem, the WASPAS approach with neutrosophic kits, often used in solving similar problems, is proposed to address this challenge (Nie et al., 2017; Stević et al., 2018; Chen et al., 2018).

Several methods are used to solve criteria problems: AHP, ANP, entropy and SWARA. The SWARA method has an advantage over the classic AHP and other methods. The SWARA method is designed for group decision making and is easy to understand for novice users as well (Keršulienė et al., 2010). Besides, it can predict expert opinions based on the relative weight of each criterion and does not require any comparative scale, such as the Saaty scale. A review paper exploring the hybrid SWARA and WASPAS approaches that evaluate criteria and alternatives have become an impetus for this combination of approaches (Mardani et al., 2017).

The article is organised as follows: section 1 provides an overview of the literature, a problem formulated in section 2 , a methodology for evaluation of residential plot selection in Vilnius city described in section 3; section 4 describes the application of the proposed methodology in Vilnius (Lithuania). Finally, discussions and conclusions are made. 


\section{Literature review}

Different processes take place in stages. Acquisition of housing starts from the location and plot selection. If one of the biggest influences on the choice of place of residence was the infrastructure 10-20 years ago, this aspect becomes less significant in the present time as the number of cars in families increases (Baušys \& Juodagalviené, 2017; Acheampong, 2018). Environmental pollution becomes more relevant (Kerimray et al., 2018), proximity to nature, projected global development of adjacent areas (Fatmi \& Habib, 2018; Tao, 2018).

The concept of sustainable development, including social, environmental and economic characteristics, fully describes the needs of the present and does not threaten future needs (Zavadskas et al., 2017b; Soflaei et al., 2017; Dahmen et al., 2018). Although the economic aspect of sustainability is still a major part of the construction industry, the importance of social sustainability is increasing (Kamali \& Hewage, 2017; Karami et al., 2017).

Assessment of urban sustainability is a complex process due to rapid urban growth, which is increasingly harming the environment (Kaklauskas et al., 2018b; Martínez-Bravo et al., 2019). Spanish scientists suggest simplifying sustainability assessments by dividing urban structures into smaller parts (Braulio-Gonzalo et al., 2018). In England, a sustainable housing development strategy is related to neighbourhood planning. This strategy has helped citizens understand the importance of housing needs (Bradley \& Sparling, 2017). Urban development is increasingly influenced by construction cycles in developed countries and especially in Europe. Based on macroeconomics and taking into account the 12 contextual indicators that assess the main social and demographic characteristics, researchers found that the number of building permits per resident (one of the most sensitive indicators) correlates with the national economy (Cecchini et al., 2019).

Practically all citizens, who are interested in the recommendations of proper planning and layout of a private house, i.e. orientation of the living room, bedrooms, kitchen and other rooms, can choose the right project. Most potential economy-class residents choose repetitive or repetitive (redesigned) house designs because of their cost. Although scientists have found that existing singlefamily houses are oriented in the desired direction, despite the random orientation of the land-plot (Almumar, 2019), choosing a small land-plot can become a problem. Studies have been carried out to determine the limitations of the plot and its built-up area to pay attention to landscape and flora preserving as part of the recreational land-plot is dedicated to relaxation and quality of life. Through a questionnaire survey and observations, researchers investigated the impact of landscape design on home prices in urban areas. They concluded that the perception of quality and quality in landscape design would be applied to residential development (Hussain et al., 2014). The size, position and environmental features of the selected land-plot can influence the thermal comfort of the future house and the energy savings due to sun exposure in the world (Almumar, 2019). Also, studies are still ongoing to compare housing prices in apartment buildings and detached houses (Holmes et al., 2019) by analysing housing information in future recession periods (Christiansen et al., 2019).

Land use is very important when buying a land-plot. When looking for a land-plot, the Lithuanian buyer encounters not only the plots of a household but also those of the agricultural or garden community use. The difference in land prices depending on land use will be significant if other conditions (engineering networks, infrastructure, environment, etc.) are similar. In most cases, plot sellers set prices based on ongoing urban development and projections of suburban housing zoning (Solecka et al., 2017; Widjonarko, 2018).

Multi-criteria decision-making methods (MCDMs) are used to help individuals or project teams to choose the best alternative, taking into account a variety of factors (Kaklauskas et al., 2018a). Selection of a plot for the construction of a single house shows a compromise among different variants. Analogous problems with hesitant fuzzy information are proposed to be solved by WASPAS (Mishra et al., 2019).

Decision-makers could use a variety of multi-criteria methods to determine the best case for plot selection. These methods are used for design solutions of various types of architecture, engineering and construction projects (Džiugaitė-Tumènienè et al., 2017; Zavadskas et al., 2019; Turskis et al., 2019a). In practice, people can implement practically all engineering solutions related to quantification. The need for qualitative assessment remains relevant for their data information. Compared to traditional methods, it is easier to evaluate elements such as justice, qualitative variables and social aspects using MCDM methods (Baušys et al., 2008; Yazdani-Chamzini et al., 2017; Sierra et al., 2018; Invidiata et al., 2018; Yan et al., 2019).

The literature review shows that, despite the existing global urban planning indicators, new sets of criteria are being sought, taking into account social and demographic characteristics. Researchers emphasise that there are no pre-defined social criteria in all contexts, and existing research can only be used as a reference (Vanclay, 2002; Valdes-Vasquez \& Klotz, 2013). Based on criteria provided by other scientists, we can create a set of criteria that will address sustainability aspects (emphasising social) that influence the choice of land-plot for a single-family house in a city or suburb of Vilnius.

\section{Problem formulation for the selection of the place of construction for the single-family house}

In this section, we will discuss issues related to economic, environmental and social aspects to select the most rational plot for a single-family house. Depending on the architectural solutions, the houses are divided into three classes: economical, medium and luxury. Plots can be divided into the same classes as houses, so it is important 
to buy a land-plot depending on your investment in the future house. The client selected for the research works in the Vilnius city; his family consists of $3-5$ persons, the living area of the planned building is $120-150 \mathrm{~m}^{2}$. To determine what criteria are most relevant to our research, we have reviewed the analysis of problem-solving.

Some residents in the city who want privacy searches a plot in a suburb or even a remote area which is far from roads and amenities; others want at least a minimum, and a third maximum infrastructure. However, the majority of modern society is increasingly dependent on critical infrastructure: energy distribution, telecommunications and IT (Saidi et al., 2018). Urban development undergoing because of urbanisation is changing the dynamics of agricultural land transformation. Research conducted by researchers using the spatial transformation method predicts new residential areas in the suburbs (Solecka et al., 2017). Infrastructure forecasting and management (Van der Duin \& Ligtvoet, 2019) has been conducted through interviews with different suppliers and adaptation to the type of innovation. Occasionally, the country's urban development policy does not work: planning does not match the interdependence between housing and the labour market, disregards the demand of the population, and stops potential infrastructure development (Cheshire, 2018). Also, vehicle growth, cycling and walking trails affect various business areas (e.g. parcel delivery) associated with urban road infrastructure (Allen et al., 2018).

$41 \%$ of Europeans live in urban centres (European Environment Agency, 2015). The market of individual houses is currently experiencing a real renaissance: the number of transactions in Vilnius and Vilnius region is equivalent to transactions made during the real estate boom: in 2019 January the number of land-plots sold is $29 \%$ higher than in the first month of the previous year (Vilnius Plan, 2018). The Vilnius City (area 401 sq. km; 536692 inhabitants) municipal general plan includes the objectives of spatial structure improvement: to preserve the peculiarity of the city related to cultural heritage and to give priority to the creation of a compact city in the central and middle zones by developing public social, transport infrastructure and system of greenery (Vilnius Plan, 2018). The city of Vilnius is not able to create infrastructure in all of the people's desired suburbs, for that purpose, the Municipal Infrastructure Development Law (Law on Municipal Infrastructure Development of the Republic of Lithuania, 2018, effective from 1 January 2020) has been prepared.

Peculiarities of residential place (location, size, purpose, neighbourhood, etc.) are important for the future potential of environmental technologies. The planned housing development is projected by applying a land plot cost of the investment calculation algorithm and evaluating land investments (Kulakov \& Baronin, 2017). Changes in the distribution of the population form a rise in housing prices, and thus land-plot prices. As the population grows, land prices in major cities are increasing, and price models are changing at their margins (Widjonarko, 2018).
A set of variables has been developed that takes into account changes in land purpose and use (Glumac et al., 2019). Infrastructure development, planned transport investments have been found to add value to the economic development zone and increase the prices of private plots (Bujanda \& Fullerton, 2017). Housing choices and price fluctuations in the country are influenced by government policies and market economy structuring (Gallent et al., 2019).

Demand for private clients and even accession to the EU in countries such as Poland, Romania and Estonia were determined by changing social and economic development (Bórawski et al., 2019). There are countries in Europe (including Lithuania) where individual houses can be built on agricultural land. In Poland, after the acquisition of cheaper land plots in agricultural areas, the reorganisation of the purpose of the plots was started (Solecka et al., 2017).

The price of a plot in Vilnius remains relatively high compared to other Lithuanian cities, despite air pollution (Zavadskas et al., 2018). This fact is true that air pollution in Vilnius did not reach the same level as in major European cities, where air pollution levels have a significant impact on the location of housing and land prices (Martínez-Bravo et al., 2019; Caravaggio et al., 2019). However, in Vilnius and its suburbs, air pollution is different, depending on motorised transport (80-90\%) and stationary and mobile industry. As the traffic flows are closer to the city centre, pollution is the highest. In our study, the distance to the boundary of Vilnius city is evaluated, which reflects the air pollution. Therefore this feature is not considered as a separate one.

According to construction experts, the price of the plot should be $20-30 \%$ of the value of the house. For the construction of a single house, the majority of Vilnius residents choose plots of 6-10 areas. But some people have the most important aspect of living environment (forest, lake). Therefore, in this case, a cheaper but larger plot (over ten ares) is often chosen. In our study, plot prices are taken from free information provided by the most visited real estate portal in Lithuania (Aruodas, 2019). Part of the metropolitan population is looking for housing in suburban or remote areas where the cost of living is lower, without taking into account transport costs. Due to the relocation of the population to the suburbs, highways are being built, and criteria for assessing sustainable transit development are being developed (Wey et al., 2016). With a plot of land, i.e. distance from certain points of concentration of infrastructure, there are also aspects of life such as the delivery of goods, garbage collection and so on (Allen et al., 2018; Hidalgo et al., 2018). Some scientists believe that transport costs are not the main factor in choosing where to live, and its role depends on the characteristics of respondents, such as travel behaviour, residential history, and respondent characteristics (Humphreys \& Ahern, 2017). In Vilnius, like other European cities, traffic jams occur during the morning and the evening peak. According to Lithuanian statistics, one of 
the reasons is the increasing number of vehicles. To solve the problem, specialists recommend choosing the public transport of the capital, bicycles, planning joint (with family members, coworkers) car trips, providing more rational routes. According to the data of 2017, about 340 thousand cars, of which 130 thousand from suburbs. The city of Vilnius chosen for our research is of asymmetric shape. Therefore the distance to its boundary has been selected for the evaluation of the distance to the city. If the plot is within the city, the distance to the nearest four-lane street is expected.

An important aspect of site selection is the potential constraints: trunk gas, high-voltage power lines, or objects included in general district plans. The land of the Garden Community is intended for agricultural purposes, but it is possible to build a dwelling house on such a plot. In this case, the cost will be lower as there is no need for spatial planning and other documents. But there are minuses: a small area plot, narrow access streets, problematic installation of water supply or sewerage, the electrical input is low power. Because a small garden house can be built without changing the purpose of the garden plot, which does not prohibit year-round living, some citizens choose this option. Bigger buyers choose parcels with a homeownership purpose, while smaller ones prefer a garden parcel. That was taken into account when selecting the plots, from which we formed two groups of plots for sale.

The privacy is also very important criteria. Everyone has the right to respect for his or her private life, home and communication (European Union Agency for Fundamental Rights, 2019; Milić \& Zhou, 2018). Residential privacy issues are addressed in research in different scientific fields. Tao (2018) conducted a research study on the impact of residential housing on living conditions. It defines the concept of privacy and states that personal privacy has four types: solitude, intimacy, anonymity and reserve, which can affect people's level of satisfaction. It has been concluded that government policy, as well as housing, has an impact on the housing privacy of the population. Housing privacy is defined as an autonomous and private area, and a lack of privacy can lead to negative side effects on emotional reactions. Living in a single house in many countries is becoming a trend towards privacy (Gugul et al., 2018).

Today, in Lithuania, developers of new quarters are increasingly turning to the needs of modern consumers, tired of the city and the eyes of neighbours, offering them more privacy. Architects are constantly looking for ingenious solutions to the problem of overcrowded settlements and sun-blocking blocks of flats, creating smaller and more remote settlements. In search of the right plot, the potential of privacy and aesthetics can only be predicted for existing and future neighbours, infrastructure changes and similar aspects. The choice of the plot place is much dependent on the crime situation in a particular district of the city (Marques et al., 2018). The security problem could be solved by installing a security system. According to the survey data, only $29 \%$ of people in Lithuania have a security system (Construction portal ASA.LT, 2017) together with all dwellings. Today, with a huge supply of security systems, the choice depends on the funds invested. That's how much money you will have to invest in security depends on where the housing will be located, i.e. how fast the security team will be able to arrive in case of an alarm. Therefore, in the study, the potential of security, privacy and aesthetics is determined by the location of the plot about the city of Vilnius and by assessing the elements of the environment: whether it is a garden plot, a residential quarter or a country area. Also, the nearby forest, lake and other aesthetic accents are appreciated.

The aesthetic view of the plot is characterised by water, forests, agricultural areas, settlements, infrastructure objects and used/abandoned land. When planning a dwelling, contextuality is also important - the harmony between landscape and buildings. The aesthetic appearance of the future house (Zavadskas et al., 2017a) is no less important for the convenience of use and the cost of the plot and construction. When choosing a plot, the aesthetics of the environment and the house elements can be predicted in advance. Apart from the landscape bordering on the land, the neighbourhood of the adjacent plots is important, and the prospects for change are: whether there will be old houses, whether settlers or nature surrounding the plot will be untouched, whether there will be blocks of flats or even commercial buildings.

One of the biggest advantages of individual houses is space. Only in towns or former garden communities, the plots of houses are small, while further away from the city it is easy to find a spacious plot that will accommodate both the house and the gazebo and a greenhouse, and will still be filled with local entertainment. Today, even in the country regions appear more modern homes with all amenities, fast internet access and convenient access. A very important aspect when choosing a plot is its orientation towards the countries of the world (north-east-westsouth). Plots that can be accessed from the north or east can be more attractive.

\section{Methodology for evaluation of residential plot selection in Vilnius city}

As urbanisation progresses, suburban infrastructure, land use, and projected zoning of housing in the suburbs are changing (Solecka et al., 2017). Our research focuses on one of the many problems of selecting a plot, namely a plot for an economy class client for building a single-family house. Land selection is treated as a multifaceted problem that requires multi-criteria evaluation. Researches have proven this approach to be an effective tool for selecting the most appropriate places (land-plots) for objects of various uses (Schitea et al., 2019; Yimen \& Dagbasi, 2019; Aktas \& Kabak, 2019). Also, we took into account that the peer-reviewed reviews supported the validity of MCDM approaches as new development principles (Mardani et al., 
2017; Yap et al., 2019). Based on the experience of other scientists, when formulating the problem of plot selection, we planned the research stages:

- Choosing alternatives,

- Choosing a research method,

- Selection of experts,

- Selection of criteria and determination of weights,

- Evaluation of alternatives by MCDM method.

Determining the best alternative from the options available is a difficult task. This fact depends on the user's priorities, which may change over time. Therefore, it is important to consider all the features that influence the alternatives carefully. According to the data of the State Enterprise "Center of Registers", about 100 plots were bought on average in Vilnius during the last six months. To select the plot alternatives, we interviewed those single-family homeowners who purchased the plots based on advertisements. Over $70 \%$ of the respondents used the services of Aruodas, the most visited real estate portal in Lithuania (Aruodas, 2019). The information in this free portal was the basis for choosing alternatives. Therefore, to determine the alternatives of the problem to be solved, we classified the plots to select a certain set of these objects. Group analysis or grouping is a method used for grouping object sets. A group or cluster is created in which objects belonging to a group are more similar to one another than in other groups (Rokach \& Maimon, 2005). Research has identified the impact of housing and job choices on the urban structure in surveys using a representative sample (Acheampong, 2018). A cluster sampling (Zhao et al., 2019) is used to classify large-scale data and the ability of each sample category to access the sample.

In Vilnius and its suburbs, the population of the plots is heterogeneous, so in our study, the plots sold in Vilnius and suburbs were divided into groups depending on the price, position to Vilnius city centre and destination. Agricultural plots were not selected. After cluster sampling, we created two groups of plots: community gardens and residential. In a simple sample, nine plots-alternatives were selected from the nest set (Figures 1 and 2, Table 1): 3 plots in gardens, 6 - residential plots. We have limited the price of the plot - up to 2.2 thousand euros for one are the distance to the Vilnius border $-23 \mathrm{~km}$.

Alternatives can be evaluated using a variety of multi-criteria decision methods that combine sustainability considerations and thus, contradictory criteria. Having evaluated the review study (Mardani et al., 2017) of applying a combination of WASPAS and SWARA approaches to analogous and similar tasks, we consider these to be appropriate in the particular case, i.e. plot for individual house selection.

Taking into account that the plot and the house are selected in Vilnius or its suburbs, all the experts and surveyed persons were selected and invited to Vilnius. Decision-makers and the rest of society need to develop mutual interaction to make reliable decisions. Research has shown that social criteria are also influenced by economic and environmental criteria, and their determination is linked to the countries involved (Di Cesare et al., 2016). Therefore, to create a list of alternatives and criteria, the experts must be selected very responsibly, taking into account their competences (Miguel et al., 2019).

Since the importance of social criteria is closely related to the context of the application, the perspective of the participants and the stages of the life cycle (Sierra et al., 2018), the chosen experts are residents of single-family houses. In this way, eleven experts were selected and invited to make decisions: seven architects/professors of architectural science, two architects designing single-family houses and two residents (doctor and professor) who are living in single-family houses.

When preparing the theoretical model of the site selection and taking into account the research carried out by the scientists, we proposed and agreed with the experts the criteria be applied when choosing a plot in Vilnius city/suburb. Due to the diversity of land prices in Vilnius city/suburbs, the list of criteria, apart from social criteria, includes the economic aspects of infrastructure, the price of land and distance to Vilnius city centre.

Other possible criteria were considered, such as restrictions: trunk gas, high-voltage power lines or objects included in the general district plans. Because the vendors provide these aspects after reviewing the city or district master plans, they are not included in the list of criteria. It is practically impossible to predict the future infrastructure of a particular plot or the surrounding land, so the valuation was based on the data provided by the sellers. The "fuel cost" criterion was also considered but rejected as the customer's workplace is not covered by the study and may change. The decision was made to evaluate the

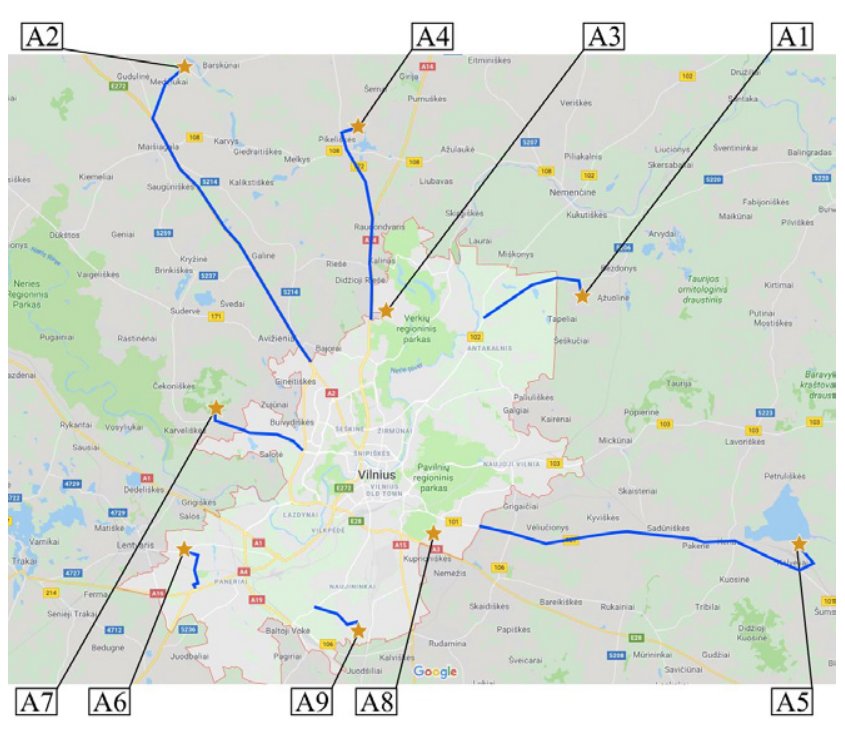

Figure 1. Chosen plots-alternatives in Vilnius city/suburb (The image is created according to an open data map, https://maps.lt) 


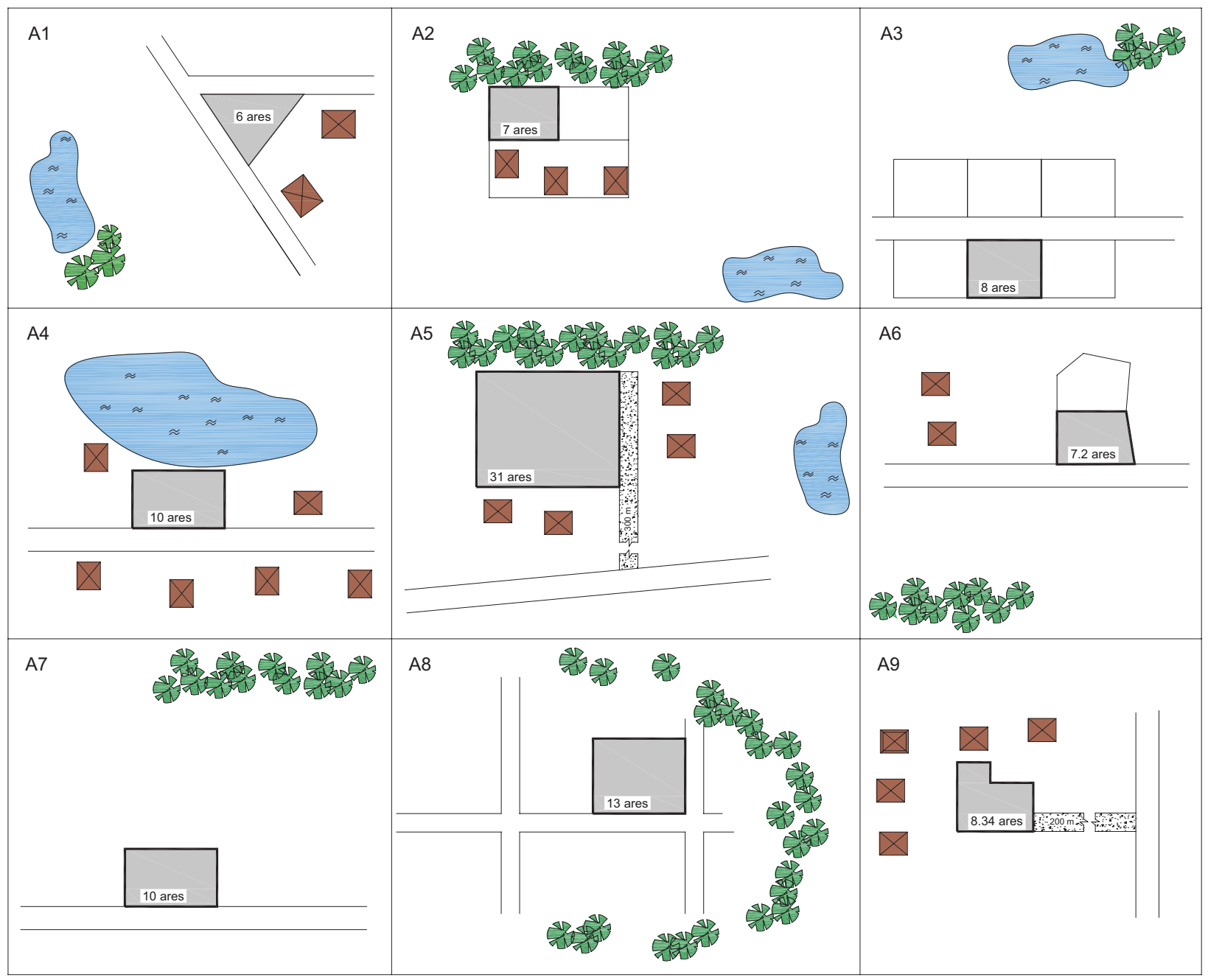

Figure 2. Schemes of alternatives

Table 1. Description of alternatives

\begin{tabular}{|c|c|c|c|c|c|c|}
\hline \multirow{2}{*}{ Alternatives } & \multicolumn{3}{|c|}{ Distance $(\mathrm{km})$ from the nearest } & \multirow{2}{*}{$\begin{array}{l}\text { Forest } \\
\text { park }\end{array}$} & \multirow{2}{*}{$\begin{array}{l}\text { Lake } \\
\text { pond }\end{array}$} & \multirow{2}{*}{$\begin{array}{l}\text { Garden community } \\
\text { / Residential }\end{array}$} \\
\hline & Preschool & School & Shop & & & \\
\hline A1, Vilnius, Antakalnis, Nemenčinès road & 4.1 & 3.9 & 6.9 & Near forest & Near lake & Garden com. \\
\hline A2, Vilnius r., Maišiagala town & 5.7 & 2.7 & 3.8 & Near forest & - & Garden com. \\
\hline A3, Vilnius, Santariškès, Sidabrès str. & 2.3 & 3.1 & 1.9 & Near park & - & Residential \\
\hline A4, Vilnius r., Pikeliškès village & 7.6 & 5.5 & 7.8 & - & Near lake & Residential \\
\hline A5, Vilnius r., Kalveliai village, Žaliašilio str. & 1.0 & 1.0 & 0.8 & Near forest & Near pond & Residential \\
\hline A6, Vilnius, Trakų Vokė, Jono Švažo str. & 1.0 & 1.1 & 1.5 & Near park & - & Residential \\
\hline A7, Vilnius, Pilaitė, Platiniškių str. & 3.6 & 4.1 & 4.1 & Near forest & - & Residential \\
\hline A8, Vilnius, Naujininkai & 2.1 & 1.3 & 1.7 & Near forest & - & Residential \\
\hline A9, Vilnius, Salininkai, Kelmijos Sodų 62 str. & 0.9 & 1.3 & 0.8 & - & - & Garden com. \\
\hline
\end{tabular}




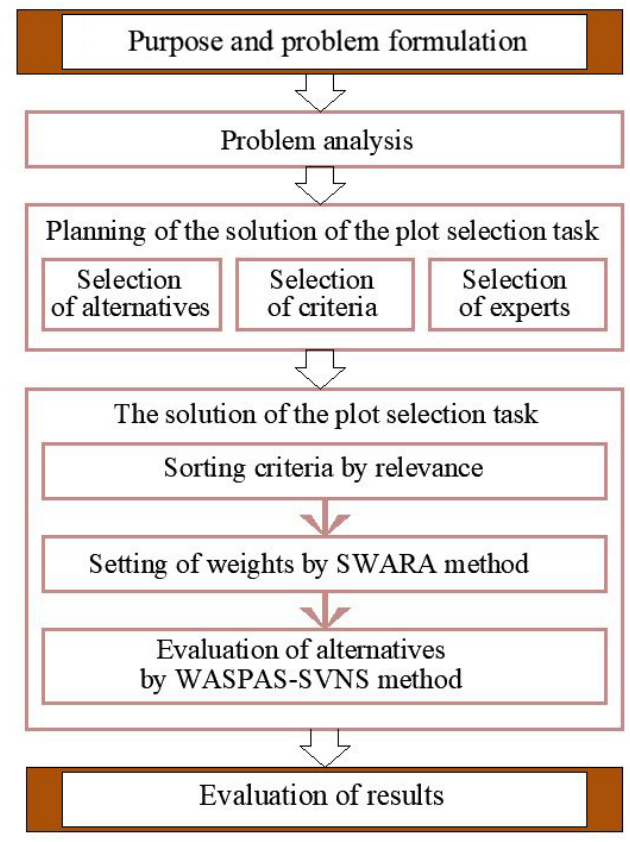

Figure 3. Stages of the selection of a plot in Vilnius city/suburb

task according to the following sustainability criteria: social (privacy, security, aesthetic view, infrastructure), environmental (distance to the centre of Vilnius) and economic (cost of land, infrastructure).

The final steps for the selection of a plot in Vilnius city/suburb are presented in Figure 3.

Although the processes associated with the set criteria, they can vary from country to country, depending on the country's culture and traditions (Tennekes et al., 2015), our model of plot selection can be applied to other cities of a similar culture.

\section{Selection of the plot location by SWARA and WASPAS-SVNS}

In most cases, the weightings of the criteria are calculated when evaluating alternatives using MCDM methods. Separate criteria that describe the impact of an object on the objective in question can be very diverse and contradictory. Therefore, it is important to select the appropriate methods for multi-criteria and calculation of the weights of the criteria or their combinations. After reviewing the MCDM tools, WASPAS and SWARA be useful in decision-making in different areas: analysing surveys, planning future objects, selecting sites for buildings (Hashemkhani Zolfani et al., 2015; Mardani et al., 2017).

\subsection{Calculation of criteria weights by SWARA method}

The SWARA (Keršulienè et al., 2010) method for calculating the weight of the criteria is appropriate for the consistency of the method, the small comparison between the criteria, the expert opinion and the evaluation (Stanujkic et al., 2019; Chalekaee et al., 2019; Valipour et al., 2019; Chen et al., 2019).
It's a simple method with clear and understandable logic. The evaluation takes place in two stages. In the first stage, the group of experts agreed and prioritised the criteria during the discussions (Table 2). In the second stage, each expert, apart from others, accepts the assessment criteria according to his or her experience and priorities. The following calculations were used to determine the weights of the criteria:

- average values of comparative importance $s_{j}$;

- determined importance coefficient

$k_{j}=s_{j}+1$;

- recalculated average weights of criteria

$$
q_{j}=\frac{q_{j-1}}{k_{j}} ;
$$

- final weights of the criteria set

$$
w_{j}=\frac{q_{j}}{\sum_{j=1}^{n} q_{j}},
$$

where: $n$ is a count of criteria.

Table 4 shows the results of the SWARA method calculation: the mean values of the relative comparative importance of the criteria obtained from Table 3 , the relative weighting coefficients of the criteria, the recalculated (intermediate) weights of the criteria and the final criteria weights. The final criteria weights are used in the multicriteria decision-making method WASPAS-SVNS.

Table 2. Sorting criteria by relevance

\begin{tabular}{|c|l|c|c|}
\hline$c_{1}-c_{6}$ & \multicolumn{1}{|c|}{ Criteria } & Optimum & Units \\
\hline$c_{1}$ & Infrastructure & $\max$ & Scores \\
\hline$c_{2}$ & Distance to Vilnius city border & $\min$ & $\mathrm{km}$ \\
\hline$c_{3}$ & Price of one are of the plot & $\min$ & Euro \\
\hline$c_{4}$ & Aesthetic view & $\max$ & Scores \\
\hline$c_{5}$ & Privacy & $\max$ & Scores \\
\hline$c_{6}$ & Security & $\max$ & Scores \\
\hline
\end{tabular}

Table 3. Peer review of the relative importance of the criteria

\begin{tabular}{|c|c|c|c|c|c|}
\hline \multirow{2}{*}{ Expert } & \multicolumn{5}{|c|}{ Pairwise comparison of criteria relative importance } \\
\cline { 2 - 6 } & $c_{1 \leftrightarrow 2}$ & $c_{2 \leftrightarrow 3}$ & $c_{3 \leftrightarrow 4}$ & $c_{4 \leftrightarrow 5}$ & $c_{5 \leftrightarrow 6}$ \\
\hline 1 & 0.3 & 0.2 & 0 & 0.8 & 0 \\
\hline 2 & 0.3 & 0.1 & 0 & 0.9 & 0 \\
\hline 3 & 0.4 & 0.3 & 0.2 & 0.2 & 0 \\
\hline 4 & 0 & 0.9 & 0 & 0.1 & 0.9 \\
\hline 5 & 0.9 & 0 & 0.1 & 0.8 & 0.1 \\
\hline 6 & 0.9 & 0 & 0.7 & 0.5 & 0.1 \\
\hline 7 & 0 & 0 & 0.9 & 0 & 0.5 \\
\hline 8 & 0.9 & 0.1 & 0.5 & 0 & 0.5 \\
\hline 9 & 0 & 0 & 0.9 & 0 & 0.8 \\
\hline 10 & 0.1 & 0.8 & 0 & 0.7 & 0 \\
\hline 11 & 0.1 & 0.9 & 0.1 & 0.1 & 0.1 \\
\hline
\end{tabular}


Table 4. Determination of criteria weights using SWARA method

\begin{tabular}{|c|c|c|c|c|}
\hline$c_{1}-c_{6}$ & $\begin{array}{c}\text { Average values of comparative } \\
\text { importance indicators, } s_{j \leftrightarrow j+1}\end{array}$ & $\begin{array}{c}\text { Coefficients of comparative } \\
\text { importance indicators, } k_{j}\end{array}$ & $\begin{array}{c}\text { Recalculated } \\
\text { (intermediate) indicators } \\
\text { weights, } w_{j}\end{array}$ & $\begin{array}{c}\text { Final indicators } \\
\text { weights, } q_{j}\end{array}$ \\
\hline$c_{1}$ & - & 1.000 & 1.000 & 0.302 \\
\hline$c_{2}$ & 0.355 & 1.355 & 0.738 & 0.223 \\
\hline$c_{3}$ & 0.300 & 1.300 & 0.568 & 0.173 \\
\hline$c_{4}$ & 0.309 & 1.309 & 0.434 & 0.131 \\
\hline$c_{5}$ & 0.372 & 1.372 & 0.316 & 0.096 \\
\hline$c_{6}$ & 0.272 & 1.272 & 0.248 & 0.075 \\
\hline & & 3.304 & \\
\hline
\end{tabular}

Table 5. Criteria and alternatives to weight ratio matrix

\begin{tabular}{|c|c|c|c|c|c|c|c|c|c|c|c|}
\hline \multirow{2}{*}{$c_{1}-c_{6}$} & \multirow{2}{*}{$\begin{array}{l}\text { Opti- } \\
\text { mum }\end{array}$} & \multirow{2}{*}{ Weight } & \multicolumn{9}{|c|}{ Alternatives } \\
\hline & & & $\mathrm{A} 1$ & A2 & A3 & A4 & A5 & A6 & A7 & A8 & A9 \\
\hline$c_{1}$ & $\max$ & 0.302 & 5.82 & 5.90 & 7.90 & 4.55 & 9.64 & 9.82 & 7.09 & 7.72 & 9.91 \\
\hline$c_{2}$ & $\min$ & 0.223 & 6.91 & 22.95 & 1.90 & 11.64 & 21.76 & 2.55 & 5.82 & 1.59 & 3.66 \\
\hline$c_{3}$ & $\min$ & 0.173 & 1.98 & 0.39 & 1.55 & 1.20 & 0.22 & 1.15 & 1.50 & 2.16 & 0.95 \\
\hline$c_{4}$ & $\max$ & 0.131 & 4.55 & 6.27 & 7.64 & 9.91 & 9.82 & 4.36 & 4.09 & 7.45 & 4.36 \\
\hline$c_{5}$ & $\max$ & 0.096 & 7.91 & 7.45 & 5.82 & 9.91 & 9.64 & 6.27 & 7.36 & 7.27 & 4.63 \\
\hline$c_{6}$ & $\max$ & 0.075 & 7.09 & 5.00 & 9.55 & 6.45 & 7.36 & 9.09 & 7.00 & 10.00 & 9.72 \\
\hline
\end{tabular}

Initial decision matrix for the residential plot problem with criteria weight is presented in Table 5.

\subsection{Selection of the location of the plot by WASPAS- SVNS method}

The detailed procedure and application of the WASPAS method are described in detail in Zavadskas et al. (2012). Although this is a relatively new MCDM method, several different modifications of the WASPAS method have been made in recent years (Baušys \& Juodagalviené, 2017; Hafezalkotob et al., 2018; Pamucar et al., 2019).

Since the expert leads to the criteria weight determination process, the SWARA method is found to be the most effective in the valuation sense. The WASPAS method includes two of the most popular objectives. Therefore, this method provides additional numerical stability. Due to the novelty and relevance of the method and its modifications, the developed WASPAS-SVNS extension is used to solve the problem.

This MCDM problem can be solved using WASPASSVNS extension of WASPAS method based on the singlevalued neutrosophic set. Then the plot selection problem can be described in the next few steps:

1. The initial information is an expert evaluation of the $i^{\text {th }}$ ithalternative and the $j^{\text {th }}$ criterion and can be shown as data $x_{i j}, i=1,2, \ldots, m ; j=1,2, \ldots, n$. In this case, the decision matrix will have a form:

$$
X=\left[\begin{array}{cccc}
x_{11} & x_{12} & \cdots & x_{1 n} \\
x_{21} & x_{22} & \cdots & x_{2 n} \\
\vdots & \vdots & \ddots & \vdots \\
x_{m 1} & x_{m 2} & \cdots & x_{m n}
\end{array}\right] .
$$

2. Next, we have to normalise aggregated decision matrix $X$ using vector normalisation technique:

$$
\tilde{x}_{i j}=\frac{x_{i j}}{\sqrt{\sum_{i=1}^{m}\left(x_{i j}\right)^{2}}} .
$$

3. Then normalised matrix $\tilde{X}$ is conversed into neutrosophic numbers, what are single-valued and neutrosophic aggregated decision matrix $\tilde{X}^{n}$ is calculated. To perform this, we need to create a relationship between single-valued neutrosophic numbers and values of criteria of alternatives, what is shown in Table 6 .

Table 6. Crisp to neutrosophic conversion expressions describing the criteria of the alternatives

\begin{tabular}{|l|c|}
\hline \multicolumn{1}{|c|}{ Crisp normalized values } & $\begin{array}{c}\text { Single-valued neutrosophic } \\
\text { numbers }\end{array}$ \\
\hline Extremely good $(\mathrm{EG}) / 1.0$ & $(1.00,0.00,0.00)$ \\
\hline Very very good $(\mathrm{VVG}) / 0.9$ & $(0.90,0.10,0.10)$ \\
\hline Very good $(\mathrm{VG}) / 0.8$ & $(0.80,0.15,0.20)$ \\
\hline Good $(\mathrm{G}) / 0.7$ & $(0.70,0.25,0.30)$ \\
\hline Medium good $(\mathrm{MG}) / 0.6$ & $(0.60,0.35,0.40)$ \\
\hline Medium $(\mathrm{M}) / 0.5$ & $(0.50,0.50,0.50)$ \\
\hline Medium bad $(\mathrm{MB}) / 0.4$ & $(0.40,0.65,0.60)$ \\
\hline Bad $(\mathrm{B}) / 0.3$ & $(0.30,0.75,0.70)$ \\
\hline Very bad $(\mathrm{VB}) / 0.2$ & $(0.20,0.85,0.80)$ \\
\hline Very very bad $(\mathrm{VVB}) / 0.1$ & $(0.10,0.90,0.90)$ \\
\hline Extremely bad $(\mathrm{EB}) / 0.0$ & $(0.00,1.00,1.00)$ \\
\hline
\end{tabular}


4. The first component of the decision depends on sum total relative importance of the alternative $i$ and can be calculated using WASPAS-SVNS methodology:

$$
\tilde{Q}_{i}^{(1)}=\sum_{j=1}^{L_{\max }} \tilde{x}_{+i j}^{n} \cdot w_{+j}^{n}+\left(\sum_{j=1}^{L_{\min }} \tilde{x}_{-i j}^{n} \cdot w_{-j}^{n}\right)^{c},
$$

where: values $\tilde{x}_{+i j}^{n}, w_{+j}^{n}$ and values $\tilde{x}_{-i j}^{n}, w_{-j}^{n}$ are associated with criteria to be maximised and minimised, respectively. The neutrosophic number and real weight number can be multiplied using the equation:

$$
\lambda \tilde{N}_{1}=\left(1-\left(1-t_{1}\right)^{\lambda}, i_{1}^{\lambda}, f_{1}^{\lambda}\right), \lambda>0 .
$$

The neutrosophic number can be expressed as $\tilde{N}_{1}=\left(t_{1}, i_{1}, f_{1}\right)$, where $t$ is membership, $i$ - indeterminacy and $t$ - non-membership degrees. Two single-valued neutrosophic numbers can be summed:

$$
\tilde{N}_{1} \oplus \tilde{N}_{2}=\left(t_{1}+t_{2}-t_{1} t_{2}, i_{1} i_{2}, f_{1} f_{2}\right) \text {. }
$$

The second part of Equation 6 consists of the complementary neutrosophic numbers. They can be described as follows:

$$
\tilde{N}_{1}^{c}=\left(f_{1}, 1-i_{1}, t_{1}\right) \text {. }
$$

5. The second component of the decision using WASPAS-SVNS methodology can be calculated:

$$
\tilde{Q}_{i}^{(2)}=\prod_{j=1}^{L_{\max }}\left(\tilde{x}_{+i j}^{n}\right)^{w_{+j}^{n}} \cdot\left(\prod_{j=1}^{L_{\min }}\left(\tilde{x}_{-i j}^{n}\right)^{w_{-j}^{n}}\right)^{c} .
$$

Terms in this equation mean the same as in 6. Two neutrosophic numbers can be multiplied as follows

$$
\tilde{N}_{1} \otimes \tilde{N}_{2}=\left(t_{1} t_{2}, i_{1}+i_{2}-i_{1} i_{2}, f_{1}+f_{2}-f_{1} f_{2}\right) .
$$

6. We can rank alternatives using WASPAS-SVNS approach after final calculation objective by the equation:

$\tilde{Q}_{i}=0.5 \tilde{Q}_{i}^{(1)}+0.5 \tilde{Q}_{i}^{(2)}$.

7. The score function $S\left(\tilde{Q}_{i}\right)$ is calculated for all alternatives $i=1,2, \ldots, m$ to be ranked in the last step.

$$
S\left(\tilde{N}_{A}\right)=\frac{3+t_{A}-2 i_{A}-f_{A}}{4}
$$

and we can evaluate alternatives sorting them in descending order $\tilde{Q}_{i}, i=1,2, \ldots, m$.

\subsection{Numerical example}

Here we will show an example of a choice of a residential house in the selected plot using MCDM framework. After performing 2 and 3 steps of WASPAS-SVNS method, we get neutrosophic aggregated decision matrix shown in Table 7.

Results of 4-7 steps of described WASPAS-SVNS method presented in Table 8 where the final ranking of alternatives performed using score functions, according to $\mathrm{Eq}(13)$.

According to the calculations of WASPAS-SVNS, the best place for the erection of a residential house was determined, and it is an alternative A6. Even though the price of the plot is average (compared to other alternatives) and the aesthetics of the area are expertly assessed both poorly, the evaluation of the infrastructure and the distance to the city of Vilnius resulted in the good position in the ranking queue. The plot is located in the city limits of Vilnius, close to Traku Vokè manor park, but far enough from the four-lane streets of the city, next to the paved access, with the existing and expanding area infrastructure, as there are many new houses in the neighbourhood.

Table 7. The aggregated decision matrix $\tilde{X}^{n}$ after the neutrosophication step

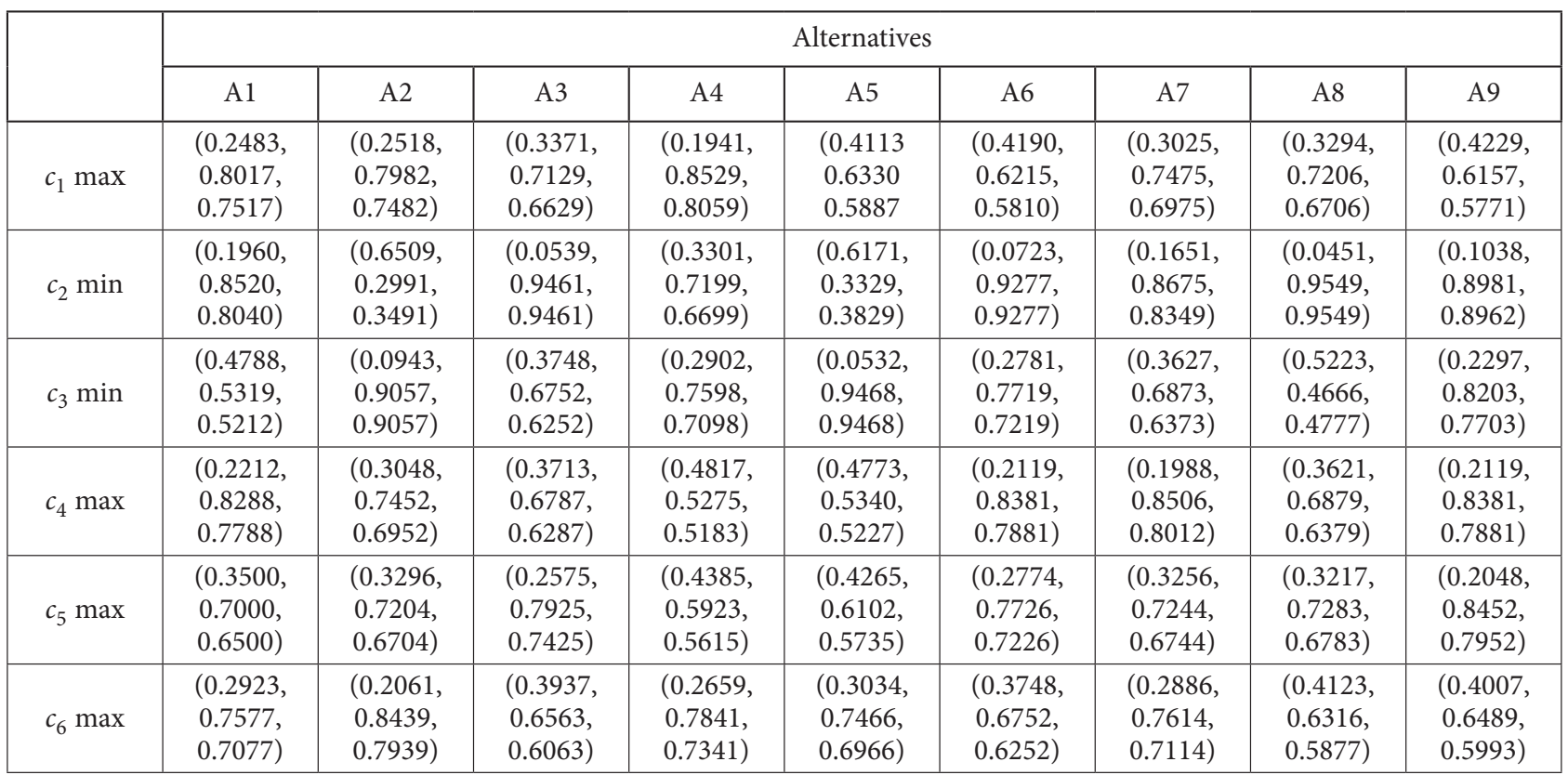


Table 8. Numerical results of WASPAS-SVNS

\begin{tabular}{|c|c|c|c|c|c|c|c|c|c|}
\hline & \multicolumn{9}{|c|}{ Alternatives } \\
\hline & $\mathrm{A} 1$ & $\mathrm{~A} 2$ & A3 & A4 & A5 & A6 & A7 & A8 & A9 \\
\hline$\tilde{Q}^{(1)}$ & $\begin{array}{c}(0.8558 \\
0.1335 \\
0.1442)\end{array}$ & $\begin{array}{c}(0.7084 \\
0.3424 \\
0.2916)\end{array}$ & $\begin{array}{c}(0.9309 \\
0.0650 \\
0.0691)\end{array}$ & $\begin{array}{c}(0.8423 \\
0.1376 \\
0.1577)\end{array}$ & $\begin{array}{c}(0.7819 \\
0.2566 \\
0.2181)\end{array}$ & $\begin{array}{c}(0.9439 \\
0.0523 \\
0.0561)\end{array}$ & $\begin{array}{c}(0.8926 \\
0.0939 \\
0.1074)\end{array}$ & $\begin{array}{c}(0.9055 \\
0.1035 \\
0.0945)\end{array}$ & $\begin{array}{l}(0.9412, \\
0.0548, \\
0.0588)\end{array}$ \\
\hline$\tilde{Q}^{(2)}$ & $\begin{array}{c}(0.1626 \\
0.8589 \\
0.8374)\end{array}$ & $\begin{array}{l}(0.1611 \\
0.8613 \\
0.8389)\end{array}$ & $\begin{array}{c}(0.1966 \\
0.8243 \\
0.8034)\end{array}$ & $\begin{array}{c}(0.1729 \\
0.8458 \\
0.8271)\end{array}$ & $\begin{array}{c}(0.2208 \\
0.7960 \\
0.7792)\end{array}$ & $\begin{array}{c}(0.1966 \\
0.8237 \\
0.8034)\end{array}$ & $\begin{array}{l}(0.1710 \\
0.8504 \\
0.8290)\end{array}$ & $\begin{array}{c}(0.1986 \\
0.8222 \\
0.8014)\end{array}$ & $\begin{array}{l}(0.1921, \\
0.8285, \\
0.8079)\end{array}$ \\
\hline$\tilde{Q}$ & $\begin{array}{c}(0.6525 \\
0.3387 \\
0.3475)\end{array}$ & $\begin{array}{l}(0.5055 \\
0.5430 \\
0.4945)\end{array}$ & $\begin{array}{c}(0.7644 \\
0.2314 \\
0.2356)\end{array}$ & $\begin{array}{l}(0.6389 \\
0.3412 \\
0.3611)\end{array}$ & $\begin{array}{c}(0.5878 \\
0.4519 \\
0.4122)\end{array}$ & $\begin{array}{c}(0.7876 \\
0.2075 \\
0.2124)\end{array}$ & $\begin{array}{c}(0.7016 \\
0.2826 \\
0.2984)\end{array}$ & $\begin{array}{c}(0.7247 \\
0.2918 \\
0.2753)\end{array}$ & $\begin{array}{l}(0.7821, \\
0.2131, \\
0.2179)\end{array}$ \\
\hline$S(\tilde{Q})$ & 0.6569 & 0.4812 & 0.7665 & 0.6489 & 0.5679 & 0.7901 & 0.7095 & 0.7165 & 0.7845 \\
\hline Rank & 6 & 9 & 3 & 7 & 8 & 1 & 5 & 4 & 2 \\
\hline
\end{tabular}

\section{Discussions}

The results obtained by applying WASPAS and SWARA methods show that due to the developed infrastructure and convenient transport links, plots located in or near Vilnius city limits are the most suitable for residential construction (alternatives A6, A9, A3 and A8). At present, factors such as the prospects for urban development are difficult to predict and evaluate. Depending on how the city or district is planned to expand, the master plan and the value of the sites will also change. Recently, the Vilnius City Development Plan (Vilnius 2030, 2018) was prepared and presented, which envisages the southern development of the city. That includes neighbourhoods such as Novice and Dew, which must become cosy, safe and attractive. Particular attention will be paid to the planting of these areas by planting adjacent parks and their public infrastructure. Such solutions can add value to the plots in the Naujininkai (A8) area.

One of the key priorities for the future is urban transport and communication. Many connections, viaducts, bridges, pedestrian and bicycle paths are planned. The reconstruction of the Vilnius-Utena road towards Pikeliškès is underway (Lithuanian Road..., 2018). The highway will be distributed to the intersection with the Vievis-Maišiagala-Nemenčine road. It is planned to construct intersections of different levels, to build pedestrian overpasses, underground pedestrian crossing, to install a noise reduction wall, to build bicycle paths. The reconstruction of the highway will improve the accessibility of the plots in Pikeliškès (A4), Nemenčinè (A1) and Maišiagala (A9) and raise them to higher positions.

As we can see, the urban development model may increase the value of some plots and raise them in the ranking of plots or vice versa, if for example a higher density of the area is envisaged.

\section{Conclusions}

The selection of a plot for residential construction is an integral part of the sustainability of urban development, which is a multifunctional problem based on an integrated assessment that is based on expert judgment. Multiple criteria approaches define the goals of sustainable development. These methods allow different interpretations of the interests of different members of society. Real estate agents forecast urban development situations and determine the relative importance of sustainability issues. Exact numbers cannot describe all development goals. Neutrosophic information modelling allows us to present true, indeterminate and false counterparts presented by independent functions. Therefore, the plot selection task must represent methods that represent these correspondences in information modelling.

The original mathematical model of the residence plot selection is presented in the study. This model is constructed including a new set of the criteria. For the solution of this model, the neutrosophic WASPAS method was applied. After evaluating the site selection criteria, the experts chose them according to the procedure mentioned above and processed them using the SWARA method. A case study conducted in Vilnius city/suburb illustrates the proposed methodology with nine land-plots selected for plot analysis. The proposed modelling and solution methodology allow the selection of the land-plot according to criteria that include economic, aesthetic and environmental requirements. The previous studies were mostly focused on the evaluation of economic aspects. However, the results obtained in this research showed that economic aspects do not always determine the ranking and that other aspects could be important too.

Based on the calculated results, the most suitable site location for the Vilnius city inhabitant was chosen, this is the A6 alternative. When evaluating the results, it can be concluded that this plot is the best because of the infrastructure, distance to the Vilnius city border and the price of one are plot. The difference between the alternatives by price per one plot of land is not very significant. Even though the number of cars in families increases, the issues of infrastructure and communication become less significant, the 
distance to the city of Vilnius is the highest in the alternatives of the worst-rated sites. Thus, the most relevant and important criteria influencing the selection of the plot are infrastructure and distance to the boundary of Vilnius city. Multiple criteria methods make decision making easier and should be used to select the optimal site for your house.

The proposed plot selection model could be extended to other MCDM methods to obtain more accurate data. It could also include an assessment of infrastructure, landuse change, and garden plot planning based on a detailed city plan. We are also planning to develop an integrated computerized method for plot selection based on a multicriteria approach. That is considered a limitation of this study and the possibility of further studies in the future.

\section{References}

Acheampong, A. (2018). Towards incorporating location choice into integrated land use and transport planning and policy: a multi-scale analysis of residential and job location choice behavior. Land Use Policy, 78, 397-409.

https://doi.org/10.1016/j.landusepol.2018.07.007

Aktas, A., \& Kabak, M. (2019). A hybrid hesitant fuzzy decisionmaking approach for evaluating solar power plant location sites. Arabian Journal for Science and Engineering, 44(8), 7235-7247. https://doi.org/10.1007/s13369-018-3604-5

Allen, J., Piecyk, M., Piotrowska, M., McLeod, F., Cherrett, T., Ghali, K., Nguyen, T., Bektas, T., Bates, O., Friday, A., Wise, S., \& Austwick, M. (2018). Understanding the impact of e-commerce on last-mile light goods vehicle activity in urban areas: the case of London. Transportation Research Part D: Transport and Environment, 61, 325-338. https://doi.org/10.1016/j.trd.2017.07.020

Almumar, M. M. S. (2019). Understanding the environmental performance of the Iraqi traditional courtyard house, Is there an order of façades orientation in randomly oriented land plots? Journal of Building Engineering, 22, 140-146. https://doi.org/10.1016/j.jobe.2018.12.004

Aruodas. (2019). Plots. Vilniaus city granary. https://www.aruodas.lt/sklypai/ (in Lithuanian)

Baušys, R., \& Juodagalvienè, B. (2017). Garage location selection for residential house by WASPAS-SVNS method. Journal of Civil Engineering and Management, 23(3), 421-429.

https://doi.org/10.3846/13923730.2016.1268645

Bausys, R., Cavallaro, F., \& Semenas, R. (2019). Application of sustainability principles for harsh environment exploration by autonomous robot. Sustainability, 11(9), 518. https://doi.org/10.3390/su11092518

Baušys, R., Dundulis, G., Kačianauskas, R., Markauskas, D., Rimkevičius, S., Stupak, E., Stupak, S., \& Šliaupa, S. (2008). Sensitivity of dynamic behaviour of the FE model: case study for the Ignalina NPP reactor building. Journal of Civil Engineering and Management, 14(2), 121-129. https://doi.org/10.3846/1392-3730.2008.14.7

Bórawski, P., Bełdycka-Bórawska, A., Szymańska, E. J., Jankowski, K. J., \& Dunn, J. W. (2019). Price volatility of agricultural land in Poland in the context of the European Union. Land Use Policy, 82, 486-496. https://doi.org/10.1016/j.landusepol.2018.11.027

Bradley, Q., \& Sparling, W. (2017). The impact of neighbourhood planning and localism on house-building in England. Housing, Theory and Society, 34(1), 106-118.

https://doi.org/10.1080/14036096.2016.1197852
Braulio-Gonzalo, M., Ruá, M. J., \& Bovea, M. D. (2018). Exploring residential urban form patterns: a Spanish case study. International Planning Studies.

https://doi.org/10.1080/13563475.2018.1552124

Bujanda, A., \& Fullerton, T. M. (2017). Impacts of transportation infrastructure on single-family property values. Applied Economics, 49(51), 5183-5199.

https://doi.org/10.1080/00036846.2017.1302064

Caravaggio, N., Caravella, S., Ishizaka, A., \& Resce, G. (2019). Beyond $\mathrm{CO}_{2}$ : a multi-criteria analysis of air pollution in Europe. Journal of Cleaner Production, 219, 576-586.

https://doi.org/10.1016/j.jclepro.2019.02.115

Cecchini, M., Zambon, I., \& Salvati, L. (2019). Housing and the city: a spatial analysis of residential building activity and the socio-demographic background in a Mediterranean city, 1990-2017. Sustainability, 11(2), 375. https://doi.org/10.3390/su11020375

Chalekaee, A., Turskis, Z., Khanzadi, M., Amiri, G. G., \& Keršulienė, V. (2019). A new hybrid MCDM model with grey numbers for the construction delay change response problem. Sustainability, 11(3), 776. https://doi.org/10.3390/su11030776

Chen, J., Wang, J., Baležentis, T., Zagurskaite, F., Streimikiene, D., \& Makutenienė, D. (2018). Multicriteria approach towards the sustainable selection of a teahouse location with sensitivity analysis. Sustainability, 10(8), 2926. https://doi.org/10.3390/su10082926

Chen, W., Panahi, M., Tsangaratos, P., Shahabi, H., Ilia, I., Panahi, S., Li, S., Jaafari, A., \& Ahmad, B. B. (2019). Applying population-based evolutionary algorithms and a neuro-fuzzy system for modeling landslide susceptibility. Catena, 172, 212-231. https://doi.org/10.1016/j.catena.2018.08.025

Cheshire, P. (2018). Broken market or broken policy? The unintended consequences of restrictive planning. Journal Indexing and Metrics. https://doi.org/10.1177/002795011824500111

Christiansen, C., Eriksen, J. N., \& Møller, S. V. (2019). Negative house price co-movements and US recessions. Regional Science and Urban Economics, 77, 382-394.

https://doi.org/10.1016/j.regsciurbeco.2019.06.007

Construction and Architecture. (2018). The implementation of BREEAM and LEED standards systems and certification requires additional investment. https://sa.lt/zyma/sertifikavimas/ (in Lithuanian)

Construction portal ASA.LT. (2017). Home security systems. http://lt.lt.allconstructions.com/portal/categories/10/1/0/1/ article/18328/namu-apsaugos-sistemos (in Lithuanian)

Dahmen, J., Bergmann, J., \& Das, M. (2018). Teardown index: impact of property values on carbon dioxide emissions of single family housing in Vancouver. Energy and Buildings, 170, 95-106. https://doi.org/10.1016/j.enbuild.2018.03.012

Di Cesare, S., Silveri, F., Sala, S., \& Petti, L. (2016). Positive impacts in social life cycle assessment: state of the art and the way forward. International Journal of Life Cycle Assessment, 23(3), 406-421. https://doi.org/10.1007/s11367-016-1169-7

Džiugaitè-Tumènienè, R., Motuzienè, V., Šiupšinskas, G., Čiuprinskas, K., \& Rogoža, A. (2017). Integrated assessment of energy supply system of an energy-efficient house. Energy and Buildings, 138, 443-454.

https://doi.org/10.1016/j.enbuild.2016.12.058

Erdogan, M., \& Kaya, I. (2019). Prioritizing failures by using hybrid multi criteria decision making methodology with a real case application. Sustainable Cities and Society, 45, 117-130. https://doi.org/10.1016/j.scs.2018.10.027

European Environment Agency. (2015). European environment: state and outlook 2015 Luxembourg: Publications Office of the 
European Union, 2015. https://www.eea.europa.eu/soer-2015/ synthesis/europos-aplinka-bukle-ir-raidos (in Lithuanian)

European Union Agency for Fundamental Rights. (2019). EU Charter of Fundamental Rights. Article 7 - Respect for private and family life. https://fra.europa.eu/en/charterpedia/ article/7-respect-private-and-family-life

Eurostat. (2019). Eurostat, Statistics Explained. Housing statistics. https://ec.europa.eu/eurostat/statistics-explained/index. php?title=Housing_statistics

Fatmi, M. R., \& Habib, M. A. (2018). Microsimulation of lifestage transitions and residential location transitions within a life-oriented integrated urban modeling system. Computers, Environment and Urban Systems, 69, 87-103. https://doi.org/10.1016/j.compenvurbsys.2018.01.003

Gallent, N., Hamiduddin, I., Stirling, P., \& Kelsey, J. (2019). Prioritising local housing needs through land-use planning in rural areas: political theatre or amenity protection? Journal of Rural Studies, 66, 11-20. https://doi.org/10.1016/j.jrurstud.2019.01.028

Glumac, B., Herrera-Gomez, M., \& Licheron, J. (2019). A hedonic urban land price index. Land Use Policy, 81, 802-812. https://doi.org/10.1016/j.landusepol.2018.11.032

Gugul, G. N., Koksal, M. A., \& Ugursal, V. I. (2018). Technoeconomical analysis of building envelope and renewable energy technology retrofits to single family homes. Energy for Sustainable Development, 45, 159-170. https://doi.org/10.1016/j.esd.2018.06.006

Guidon, S., Wicki, M., Bernauer, T., \& Axhausen, K. (2019). The social aspect of residential location choice: on the trade-off between proximity to social contacts and commuting. Journal of Transport Geography, 74, 333-340.

https://doi.org/10.1016/j.jtrangeo.2018.12.008

Hafezalkotob, A., Hami-Dindar, A., Rabie, N., \& Hafezalkotob, A. (2018). A decision support system for agricultural machines and equipment selection: a case study on olive harvester machines. Computers and Electronics in Agriculture, 148, 207-216. https://doi.org/10.1016/j.compag.2018.03.012

Hashemkhani Zolfani, S., Maknoon, R., \& Zavadskas, E. K. (2015). Multiple Nash equilibriums and evaluation of strategies. New application of MCDM methods. Journal of Business Economics and Management, 16(2), 290-306. https://doi.org/10.3846/16111699.2014.967715

Hidalgo, D., Martín-Marroquín, J. M., Corona, F., \& Juaristi, J. L. (2018). Sustainable vacuum waste collection systems in areas of difficult access. Tunnelling and Underground Space Technology, 81, 221-227. https://doi.org/10.1016/j.tust.2018.07.026

Hiller, N., \& Lerbs, O. W. (2016). Aging and urban house prices. Regional Science and Urban Economics, 60, 276-291. https://doi.org/10.1016/j.regsciurbeco.2016.07.010

Holmes, M. J., Otero, J., \& Panagiotidis, T. (2019). Property heterogeneity and convergence club formation among local house prices. Journal of Housing Economics, 43, 1-13. https://doi.org/10.1016/j.jhe.2018.09.002

Humphreys, J., \& Ahern, A. (2017). Is travel based residential self-selection a significant influence in modal choice and household location decisions? Transport Policy, 75, 150-160. https://doi.org/10.1016/j.tranpol.2017.04.002

Hussain, M. R. M., Tukiman, I., Zen, I., \& Shahli, F. M. (2014). The impact of landscape design on house prices and values in residential development in urban areas. APCBEE Procedia, 10, 316-320. https://doi.org/10.1016/j.apcbee.2014.10.059

Invidiata, A., Lavagna, M., \& Ghisi, E. (2018). Selecting design strategies using multi-criteria decision making to improve the sustainability of buildings. Building and Environment, 139, 58-68. https://doi.org/10.1016/j.buildenv.2018.04.041
Kaklauskas, A., Zavadskas, E. K., Banaitis, A., Meidute-Kavaliauskiene, I., Liberman, A., Dzitac, S., Ubarte, I., Binkyte, A., Cerkauskas, J., Kuzminske, A., \& Naumcik, A. (2018a). A neuro-advertising property video recommendation system. Technological Forecasting and Social Change, 131, 78-93. https://doi.org/10.1016/j.techfore.2017.07.011

Kaklauskas, A., Zavadskas, E. K., Radzeviciene, A., Ubarte, I., Podviezko, A., Podvezko, V., Kuzminske, A., Banaitis, A., Binkyte, A., \& Bucinskas, V. (2018b). Quality of city life multiple criteria analysis. Cities, 72, 82-93.

https://doi.org/10.1016/j.cities.2017.08.002

Kamali, M., \& Hewage, K. (2017). Development of performance criteria for sustainability evaluation of modular versus conventional construction methods. Journal of Cleaner Production, 142(4), 3592-3606. https://doi.org/10.1016/j.jclepro.2016.10.108

Kaoula, D., \& Bouchair, A. (2020). Identification of the best material-energy-climate compatibility for five ecological houses and the contribution of their impact sources to the overall balance. Sustainable Cities and Society, 52, 101781. https://doi.org/10.1016/j.scs.2019.101781

Karami, S., Karami, E., Buys, L., \& Drogemuller, R. (2017). System dynamic simulation: a new method in social impact assessment (SIA). Environmental Impact Assessment Review, 62, 25-34. https://doi.org/10.1016/j.eiar.2016.07.009

Kerimray, A., Suleimenov, B., De Miglio, R., Rojas-Solórzano, L., Torkmahalleh, M. A., \& Ó Gallachóir, B. P. (2018). Investigating the energy transition to a coal free residential sector in Kazakhstan using a regionally disaggregated energy systems model. Journal of Cleaner Production, 196, 1532-1548. https://doi.org/10.1016/j.jclepro.2018.06.158

Keršulienė, V., Zavadskas, E. K., \& Turskis, Z. (2010). Selection of rational dispute resolution method by applying new stepwise weight assessment ratio analysis (SWARA). Journal of Business Economics and Management, 11(2), 243-258. https://doi.org/10.3846/jbem.2010.12

Kokaraki, N., Hopfe, C. J., Robinson, E., \& Nikolaidou, E. (2019). Testing the reliability of deterministic multi-criteria decisionmaking methods using building performance simulation. Renewable and Sustainable Energy Reviews, 112, 991-1007. https://doi.org/10.1016/j.rser.2019.06.018

Konstantinos, I., Georgios, T., \& Garyfalos, A. (2019). A decision support system methodology for selecting wind farm installation locations using AHP and TOPSIS: case study in Eastern Macedonia and Thrace region, Greece. Energy Policy, 132, 232-246. https://doi.org/10.1016/j.enpol.2019.05.020

Kulakov, K., \& Baronin, S. (2017). Methodical modeling of the investment value of land plots for housing development. International Science Conference SPbWOSCE-2016 "SMART City", 106, 8. https://doi.org/10.1051/matecconf/201710608100

Law on Municipal Infrastructure Development of the Republic of Lithuania. (2018). Draft Law on Municipal Infrastructure Development of the Republic of Lithuania (No. 18-14021). https://eseimas.lrs.lt/portal/legalAct/lt/TAP/4b0e8710f4a311e8b5e8d68 1eb86525b?positionInSearchResults=7\&searchModelUUID $=0$ f 9d0c98-695e-498a-8049-e58b45341583 (in Lithuanian)

Lithuanian Department of Statistics. (2013). Population and its territorial distribution. Lithuanian population and housing census 2011. Vilnius. https://www.stat.gov.lt/ (in Lithuanian)

Lithuanian Road Administration under the Ministry of Transport and Communications. (2018). Stages of reconstruction of road A14 Vilnius-Utena, 2018. https://lakd.lrv.lt/lt/naujienos/pradedamas-naujas-kelio-a14-vilnius-utena-rekonstravimo-etapas (in Lithuanian) 
Luttik, J. (2000). The value of trees, water and open space as reflected by house prices in the Netherlands. Landscape and Urban Planning, 48, 161-167.

https://doi.org/10.1016/S0169-2046(00)00039-6

Mardani, A., Jusoh, A., Halicka, K., Ejdys, J., Magruk, A., Norulkamar U., \& Ahmad, U. (2018). Determining the utility in management by using multi-criteria decision support tools: a review. Economic Research-Ekonomska Istraživanja, 31(1), $1666-1716$.

https://doi.org/10.1080/1331677X.2018.1488600

Mardani, A., Nilashi, M., Zakuan, N., Loganathan, N., Soheilirad, S., Saman, M. Z. M., \& Ibrahim, O. (2017). A systematic review and meta-analysis of SWARA and WASPAS methods: theory and applications with recent fuzzy developments. Applied Soft Computing, 57, 265-292.

https://doi.org/10.1016/j.asoc.2017.03.045

Marques, S. C. R., Ferreira, F. A. F., Meidute-Kavaliauskienè, I., \& Banaitis, A. (2018). Classifying urban residential areas based on their exposure to crime: a constructivist approach. Sustainable Cities and Society, 39, 418-429.

https://doi.org/10.1016/j.scs.2018.03.005

Martínez-Bravo, M. M., Martínez-del-Río, J., \& Antolín-López, R. (2019). Trade-offs among urban sustainability, pollution and livability in European cities. Journal of Cleaner Production, 224, 651-660. https://doi.org/10.1016/j.jclepro.2019.03.110

Miguel, B. P., Ferreira, F. A. F., Banaitis, A., Banaitienè, N., Meiduté-Kavaliauskienė, I., \& Falcão, P. F. (2019). An expanded conceptualization of "smart" cities: adding value with fuzzy cognitive maps. E\&M Economics and ManagementE\&M Ekonomie a Management, 22(1), 4-21.

https://doi.org/10.15240/tul/001/2019-1-001

Milić, J., \& Zhou, J. (2018). Residential satisfaction among young people in post-socialist countries: the case of Serbia. Journal of Housing and the Built Environment, 33(4), 715-730. https://doi.org/10.1007/s10901-017-9579-9

Mishra, A. R., \& Rani, P. (2018). Interval-valued intuitionistic fuzzy WASPAS method: application in reservoir flood control management policy. Group Decision and Negotiation, 27, 1047-1078. https://doi.org/10.1007/s10726-018-9593-7

Mishra, A. R., Rani, P., Pardasani, K. R., \& Mardani, A. (2019). A novel hesitant fuzzy WASPAS method for assessment of green supplier problem based on exponential information measures. Journal of Cleaner Production, 238, 117901. https://doi.org/10.1016/j.jclepro.2019.117901

Mohammed, A., Harris, I., \& Govindan, K. (2019). A hybrid MCDM-FMOO approach for sustainable supplier selection and order allocation. International Journal of Production Economics, 217, 171-184.

https://doi.org/10.1016/j.ijpe.2019.02.003

Motuzienè, V., Rogoža, A., Lapinskienė, V., \& Vilutienė, T. (2016). Construction solutions for energy efficient singlefamily house based on its life cycle multi-criteria analysis: a case study. Journal of Cleaner Production, 112, 532-541. https://doi.org/10.1016/j.jclepro.2015.08.103

Nie, R., Wang, J., \& Zhang, H. (2017). Solving solar-wind power station location problem using an extended weighted aggregated sum product assessment (WASPAS) technique with interval neutrosophic sets. Symmetry, 9(7), 106. https://doi.org/10.3390/sym9070106

Ober-Haus. (2019). Investment plot: how to choose a plot for successful investment, 2019. https://www.ober-haus.lt/ (in Lithuanian)

Ortiz, J., Fonseca, A., Salom, J., Garrido, N., Fonseca, P., \& Russo, V. (2016). Comfort and economic criteria for selecting passive measures for the energy refurbishment of residential buildings in Catalonia, Energy and Buildings, 110, 195-210. https://doi.org/10.1016/j.enbuild.2015.10.022

Pamucar, D., Chatterjee, K., \& Zavadskas, E. K. (2019). Assessment of third-party logistics provider using multi-criteria decision making approach based on interval rough numbers. Computers \& Industrial Engineering, 127, 383-407.

https://doi.org/10.1016/j.cie.2018.10.023

Peng, X., \& Dai, J. (2017). Hesitant fuzzy soft decision making methods based on WASPAS, MABAC and COPRAS with combined weights. Journal of Intelligent \& Fuzzy Systems, 33(2), 1313-1325. https://doi.org/10.3233/JIFS-17124

Petrovic, B., Myhren, J. A., Zhang, X., Wallhagen, M., \& Eriksson, O. (2019). Life cycle assessment of a wooden single-family house in Sweden. Applied Energy, 251, 113253. https://doi.org/10.1016/j.apenergy.2019.05.056

Rokach, L., \& Maimon, O. (2005). Clustering methods. In The data mining and knowledge discovery handbook (pp. 321-352). Springer-Verlag. https://doi.org/10.1007/0-387-25465-X_15

Saidi, S., Kattan, L., Jayasinghe, P., Hettiaratchi, P., \& Taron, J. (2018). Integrated infrastructure systems - a review. Sustainable Cities and Society, 36, 1-11.

https://doi.org/10.1016/j.scs.2017.09.022

Schitea, D., Deveci, M., Iordache, M., Bilgili, K., Akyurt, I. Z., \& Iordachea, I. (2019). Hydrogen mobility roll-up site selection using intuitionistic fuzzy sets based WASPAS, COPRAS and EDAS. International Journal of Hydrogen Energy, 44(16), 8585-8600. https://doi.org/10.1016/j.ijhydene.2019.02.011

Si, J., Marjanovic-Halburd, L., Nasiri, F., \& Bell, S. (2016). Assessment of building-integrated green technologies: a review and case study on applications of multi-criteria decision making (MCDM) method. Sustainable Cities and Society, 27, 106-115. https://doi.org/10.1016/j.scs.2016.06.013

Sierra, L. A., Yepes, V., \& Pellicer, E. (2018). A review of multicriteria assessment of the social sustainability of infrastructures. Journal of Cleaner Production, 187, 496-513. https://doi.org/10.1016/j.jclepro.2018.03.022

Soflaei, F., Shokouhian, M., \& Zhu, W. (2017). Socio-environmental sustainability in traditional courtyard houses of Iran and China. Renewable and Sustainable Energy Reviews, 69, 1147-1169. https://doi.org/10.1016/j.rser.2016.09.130

Solecka, I., Sylla, M., \& Świąder, M. (2017). Urban sprawl impact on farmland conversion in suburban area of Wroclaw, Poland. IOP Conference Series: Materials Science and Engineering, 245. https://doi.org/10.1088/1757-899X/245/7/072002

Stanujkic, D., Karabasevic, D., Zavadskas, E. K., Smarandache, F., \& Cavallaro, F. (2019). An approach to determining customer satisfaction in traditional Serbian restaurants. Entrepreneurship and Sustainability Issues, 6(3), 1127-1138.

https://doi.org/10.9770/jesi.2019.6.3(5)

Stević, Ž., Pamučar, D., Subotić, M., Antuchevičiene, J., \& Zavadskas, E. K. (2018). The location selection for roundabout construction using rough BWM-Rough WASPAS approach based on a new rough Hamy aggregator. Sustainability, 10(8), 2817. https://doi.org/10.3390/su10082817

Tao, L. W. (2018). Survey of the critical issue of the public housing privacy to influence on residents' living condition in Hong Kong. HBRC Journal, 14, 288-293. https://doi.org/10.1016/j.hbrcj.2016.11.005

Tennekes, J., Harbers, A., \& Buitelaar, E. (2015). Institutional arrangements and the morphology of residential development in the Netherlands, Flanders and North Rhine-Westphalia. European Planning Studies, 23, 2165-2183. https://doi.org/10.1080/09654313.2015.1018437 
Turskis, Z., Goranin, N., Nurusheva, A., \& Boranbayev, S. (2019b). A fuzzy WASPAS-based approach to determine critical information infrastructures of EU sustainable development. Sustainability, 11(2), 424. https://doi.org/10.3390/su11020424

Turskis, Z., Urbonas, K., \& Daniūnas, A. (2019a). A hybrid fuzzy group multi-criteria assessment of structural solutions of the symmetric frame alternatives. Symmetry, 11(2), 1-20. https://doi.org/10.3390/sym11020261

Valdes-Vasquez, R., \& Klotz, L. E. (2013). Social sustainability considerations during planning and design: framework of processes for construction projects. Journal of Construction Engineering and Management, 139(1). https://ascelibrary.org/ doi/abs/10.1061/(ASCE)CO.1943-7862.0000566

Valipour, A., Yahaya, N., Md Noor, N., Valipour, I., \& Tamošaitiene, J. (2019). A SWARA-COPRAS approach to the allocation of risk in water and sewerage public-private partnership projects in Malaysia. International Journal of Strategic Property Management, 23(4), 269-283.

https://doi.org/10.3846/ijspm.2019.8066

Van der Duin, P., \& Ligtvoet, A. (2019). Lines into the future. Exploring how Dutch infrastructure providers organize and manage their foresight processes. Futures, 105, 187-198. https://doi.org/10.1016/j.futures.2018.10.006

Vanclay, F. (2002). Conceptualising social impacts. Environmental Impact Assessment Review, 22(3), 183-211. https://doi.org/10.1016/S0195-9255(01)00105-6

Vilnius 2030. (2018). Vilnius 2030 - general plan solutions presented to Vilnius residents, 2018. https://vilnius.lt/lt/2018/06/01/ vilnius-2030-vilnieciams-pristatyti-bendrojo-plano-sprendiniai/ (in Lithuanian)

Vilnius Plan. (2018). General plan of Vilnius city municipality territory, 2018. Preparing. Vilnius plan. https://vilnius.lt/lt/ savivaldybe/miesto-pletra/vilniaus-miesto-bendrasis-planas/ (in Lithuanian)

Wey, W., Zhang, H., \& Chang, Y. (2016). Alternative transit-oriented development evaluation in sustainable built environment planning. Habitat International, 55, 109-123. https://doi.org/10.1016/j.habitatint.2016.03.003

Widjonarko, W. (2018). Spatial modelling of land price in the Semarang city. IOP Conference Series: Earth and Environmental Science, 123. https://doi.org/10.1088/1755-1315/123/1/012029

Yan, C., Rousse, D., \& Glaus, M. (2019). Multi-criteria decision analysis ranking alternative heating systems for remote communities in Nunavik. Journal of Cleaner Production, 208, 1488-1497. https://doi.org/10.1016/j.jclepro.2018.10.104

Yap, J. Y. L., Ho, C. C., \& Ting, C.-Y. (2019). A systematic review of the applications of multi-criteria decision-making methods in site selection problems. Built Environment Project and Asset Management, 9(4), 548-563.

https://doi.org/10.1108/BEPAM-05-2018-0078

Yazdani-Chamzini, A., Zavadskas, E. K., Antucheviciene, J., \& Bausys, R. (2017). A model for shovel capital cost estimation, using a hybrid model of multivariate regression and neural networks. Symmetry, 9(12), 1-14.

https://doi.org/10.3390/sym9120298

Yimen, N., \& Dagbasi, M. (2019). Multi-attribute decisionmaking: applying a modified Brown-Gibson model and RETScreen software to the optimal location process of utilityscale photovoltaic plants. Processes, 7(8), 505.

https://doi.org/10.3390/pr7080505

Zamani, Z., Heidari, S., \& Hanachi, P. (2018). Reviewing the thermal and microclimatic function of courtyards. Renewable and Sustainable Energy Reviews, 93, 580-595.

https://doi.org/10.1016/j.rser.2018.05.055

Zavadskas, E. K., Bausys, R., \& Antucheviciene, J. (2019). Civil engineering and symmetry. Symmetry, 11(4), 1-6.

https://doi.org/10.3390/sym11040501

Zavadskas, E. K., Bausys, R., \& Mazonaviciute, I. (2019). Safety evaluation methodology of urban public parks by multi-criteria decision making. Landscape and Urban Planning, 189, 372-381. https://doi.org/10.1016/j.landurbplan.2019.05.014

Zavadskas, E. K., Bausys, R., Juodagalviene, B., \& Garnyte-Sapranaviciene, I. (2017a). Model for residential house element and material selection by neutrosophic MULTIMOORA method. Engineering Applications of Artificial Intelligence, 64, 315-324. https://doi.org/10.1016/j.engappai.2017.06.020

Zavadskas, E. K., Bausys, R., Kaklauskas, A., Ubarte, I., Kuzminske, A., \& Gudiene, N. (2017b). Sustainable market valuation of buildings by the single-valued neutrosophic MAMVA method. Applied Soft Computing, 57, 74-87. https://doi.org/10.1016/j.asoc.2017.03.040

Zavadskas, E. K., Kaklauskas, A., Kalibatas, D., Turskis, Z., Krutinis, M., \& Bartkienè, L. (2018). Applying the TOPSIS-F method to assess air pollution in Vilnius. Environmental Engineering and Management Journal, 17(9), 2041-2050. https://doi.org/10.30638/eemj.2018.203

Zavadskas, E. K., Turskis, Z., Antucheviciene, J., \& Zakarevicius, A. (2012). Optimization of weighted aggregated sum product assessment. Electronics and Electrical Engineering, 122(6), 3-6. https://doi.org/10.5755/j01.eee.122.6.1810

Zhao, X., Liang, J., \& Dang, C. (2019). A stratified sampling based clustering algorithm for large-scale data. KnowledgeBased Systems, 163, 416-428.

https://doi.org/10.1016/j.knosys.2018.09.007 